\title{
The Impact of Timing and Mode of Entry on Successor Development and Successful Succession
}

\author{
Michael Harvey, Rodney E. Evans
}

\begin{abstract}
Family businesses frequently are disrupted by the process of succession of leadership and ownership. This article focuses on causes of the conflict, how to manage succession once siblings have entered the family business, and succession planning by managing the timing and mode of sibling entry into the family business.
\end{abstract}

Research into succession in family businesses (Christensen, 1953) has yielded significant insights: the need for participation of the next generation in the succession process (Longenecker and Schoen, 1975, 1978; Davis, 1982; Patrick, 1985; Ward, 1987; Barach, Gantisky, Carson, and Doochin, 1988); the problems of selecting successors and managing the succession process from the founder's viewpoint (Barnes and Hershon, 1976; Danco, 1980, 1982; Schein, 1983; Bork, 1986; Handler, 1990; Swogger, 1991); assessment of family business succession from the next generation's viewpoint (Blotnick, 1984; Patrick, 1985; Birley, 1986; Barnes, 1988; Rogal, 1989; Dumas, 1990; Friedman, 1991; Handler, 1990); and the impact of daughters on the succession process (Barnes, 1988; Dumas, 1990; GillisDonovan, 1990; Hollander and Bukowitz, 1990). In addition, the literature contains many general descriptions of how to "manage" succession and avoid dysfunctional conflict in family businesses (Davis, 1968; Barnes and Hershon, 1976; Danco, 1982; Ambrose, 1983; Bork, 1986; Lansberg, 1988; Tashakori, 1980; Rosenblatt, de Mik, Anderson, and Johnson, 1985; Cohen, 1992; Jaffe, 1990). Even with this extensive research effort, two interesting facets of succession in family business have received limited consideration: (1) the role of timing in siblings' entrance into the business and (2) the entry modes open to siblings to become involved in their family business. Much of the past research has concentrated on ex post facto analysis, conflict resolution, and management of the succession process after the siblings have become participants in the family business. 
This article explores the wide variety of family business involvement for siblings and advocates the proactive management of the timing of their entrance into the family business. By anticipating the "predictable" critical junctures in a sibling's career and family, life cycle participation in the family business may be enriched. At the same time, because all junctures are not predictable, unexpected entry junctures and mechanisms to diminish the negative impact of the "sudden need" for a successor are explored. The final aspect of the article discusses a sibling entry timing division process. This process points to the conclusion that succession planning and management should begin almost when the family business is formed. Each of the phases of the research are accompanied by research propositions that can be tested by other researchers in the future.

\section{Sibling Involvement in Family Business}

The basic premise of this research effort is that family business owners would like to perpetuate their organizations, and that the most likely candidates to form the successor pool are the extended family, that is, siblings and their spouses, children of the founder, or the controlling family generation. (For ease of communications, the term founder is used throughout this article to represent the present controlling individual in the family business.) When viewing potential family members as successors, the organization has four potential outcomes relative to their employment as a successor (see Figure 1).

Ideally, the organization would like to attract a motivated, qualified member to take over the leadership of the family business (Handler, 1990). But just as important to the organization is to identify unqualified, unmotivated offspring (and their families) to keep them from rising to power within the organization (Danco, 1982). The remaining situations described in Figure 1 illustrate two negative outcomes for the family operation. First, a qualified family member is not motivated to assume a leadership role in the company. This could occur because the sibling or spouse has developed a successful professional career outside the family business. In this situation, the family member

\section{Figure 1. "Perfect World" Decision Criteria for Family Member Involvement}

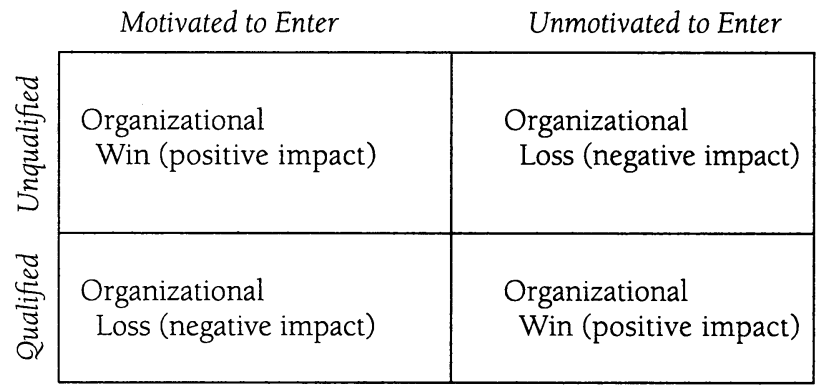


attends law school, medical school, or graduate business school and becomes an expert or specialist in an area that produces both personal enjoyment and professional success. This scenario can also occur if the family member in power does not have a well-articulated succession plan (Beckhard and Dyer, 1983b; Cicirelli, 1985; Dyer, 1986). A second, and equally unfortunate, circumstance occurs when an unqualified sibling or spouse is motivated to take over the leadership of the company but lacks the required skills. Considering these two undesirable conditions, it is not difficult to accept the report that only 30 percent of family organizations survive the transition to the second generation (Beckhard and Dyer, 1983a).

\section{Planning for Succession Through Entry Timing}

If planning for succession is delayed until the founder's children are grown, or if they are presently employed by the family business, a form of succession paralysis can occur (Malone and Jenste, 1992). Managing the timing of siblings entering the family business has an "Orwellian" connotation to it, but the managing generation must recognize that successful succession requires planning to minimize conflicts.

The family/managing generation should start the evaluation of siblings early and be aware of natural junctures in the professional career that could be opportune times to encourage a sibling to enter the family business. Figure 2 illustrates a number of incremental opportunities a sibling has during a career to enter the family business.

Figure 2. Entrepreneurial Strategic Windows of Opportunity

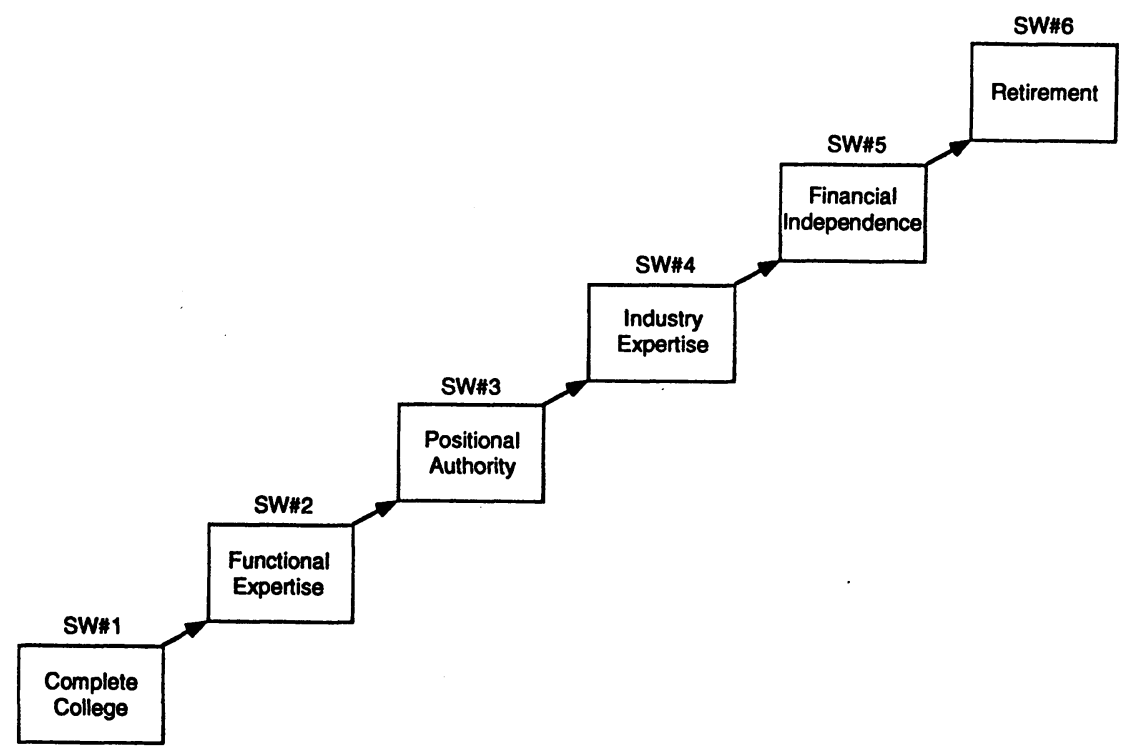


For many reasons, the completion of a college degree is the beginning of a series of "strategic windows." These strategic windows define the limited periods when there is a "fit" between the competencies of an individual and the requirements of the family business. These are the points of opportunity for the individual to enter the family business. For example, college completion is a prominent event. The process of acquiring a college degree is frequently accompanied not only by the attainment of business perspectives and skills but by a personal maturation as well, both of which will be useful in making a contribution to the family business. At the completion of college, there are fewer opportunity costs, there is high motivation, there is an exceptional level of energy and drive, and, if unsuccessful in the family business, the damage to one's career can be contained. Conversely, of course, the newly graduated son or daughter is likely to have limited relevant business and managerial experience. His or her store of resources and management experience is limited and is probably accompanied by an unknown ability to deal with unexpected events. It should also be noted that if individuals are successful in the family business, they will be less likely to leave to start their own business.

At the other end of the career life cycle continuum, the retiree has almost the mirror image of strengths and weaknesses of the recent college graduate. Positioning the new college graduate and the retiree as polar extremes provides a convenient beginning and end to the career evolution process. In many ways, these extremes are easy to define and describe, and they lack the shortcoming of being related to chronological age. Graduation presumably makes one the recipient of new, but untested, skills, and, therefore, makes one eligible for an entry-level position whatever one's age. Retirement implies some level of economic success; one has the income for food and shelter, and it implies the desire to step out of the active economic pursuit. Of course, there will always be exceptions to these generalized characteristics. In fact, the most successful family member will likely not exhibit an identical set of weaknesses and strengths, but the majority of individuals in these two stages will have a similar set of personal behavioral characteristics.

Determining the occurrence of the intermediate phases of the career life cycle is more difficult. What is the individual's level of functional and industry expertise? How much positional authority does the individual hold, and how long has it been held? How much money makes one financially independent? Does every individual experience most or all of the phases? Is the sequence consistent across individuals? Are there reasonable time periods one can expect to spend between phases? These questions tend to be grouped into two categories: (1) timing and (2) intensity of experience. With respect to timing, the obvious judges are the individuals themselves and the power holder in the family business. Indicators can help determine when a family member should enter the family business. For example, a promotion from an entry-level position may be an indicator of mastering functional skills. An entry-level accountant passes the CPA exam, conducts client audits for four years, and is promoted to accounts 
manager. The organization and the individual's profession have signaled that this individual has reached a functional expertise plateau. A financial analyst observes that advertised qualifications for positions at a rival firm are below his or her own. A sales representative observes a contemporary with similar performance and experience being shifted to a larger, more lucrative territory. A scientist begins to read and understand the Wall Street Journal. All of these are indications of growth and show an independent assessment of the appropriateness of the family member's background to date. A strategic window may be open to apply those skills and expertise in the family business.

To illustrate a measure of positional authority, a typical salesperson's career helps illuminate the concept. The reward for successful selling is often a move into the management of other salespeople, the logic being that successful salespeople will be able to identify, develop, and motivate behavior similar to their own in others. After a series of promotions in the sales management arena, (district manager to regional manager to national manager), the individual may be considered for general management of the organization. At each of these junctures, there may be an opportunity for this individual to take the acquired skills and become a contributing member of the family business. Judgment on when to enter the family business can be a critical issue. There are times when the window is open if the individual is prepared and motivated to enter the family business, and this window is observable directly by all concerned. The opportunity of becoming a part of the family business may occur many times throughout the entire career life cycle. Founders may focus only on entry-level positions for siblings and, therefore, not "manage" the timing of entry at other career junctures. In doing so, they initiate the conflict with succession themselves.

Still, the concept of strategic windows is useful for the long-run planning of the managing generation. It helps define the process of family succession in the context of the more customary career development process. Consequently, a managing generation that actively anticipates career events for siblings helps alleviate the potential "log jam" issue relative to succession. All too often, families feel that children should immediately work for the family business; if the children resist, it is interpreted as disloyalty or lack of interest in the family. business. By implication, the sibling has a reduced possibility of taking over the leadership of the family business. The career life cycle allows more accurate assessment of the company's needs and the skill portfolio of the siblings by what stage of life cycle they are in at the time.

The managing generation also needs to determine the level of commitment they want or expect out of each of the siblings in relation to the family business. One means of staggering sibling entry into the family business is to use varying levels of time commitment for each sibling, such as full-time or parttime employment or an exclusively advisory capacity. Table 1 illustrates the level of commitment and the strategic window in the sibling's career as well as what type of impact the family might expect from the entry. The time commitment dimension permits the controlling generation an additional variable 


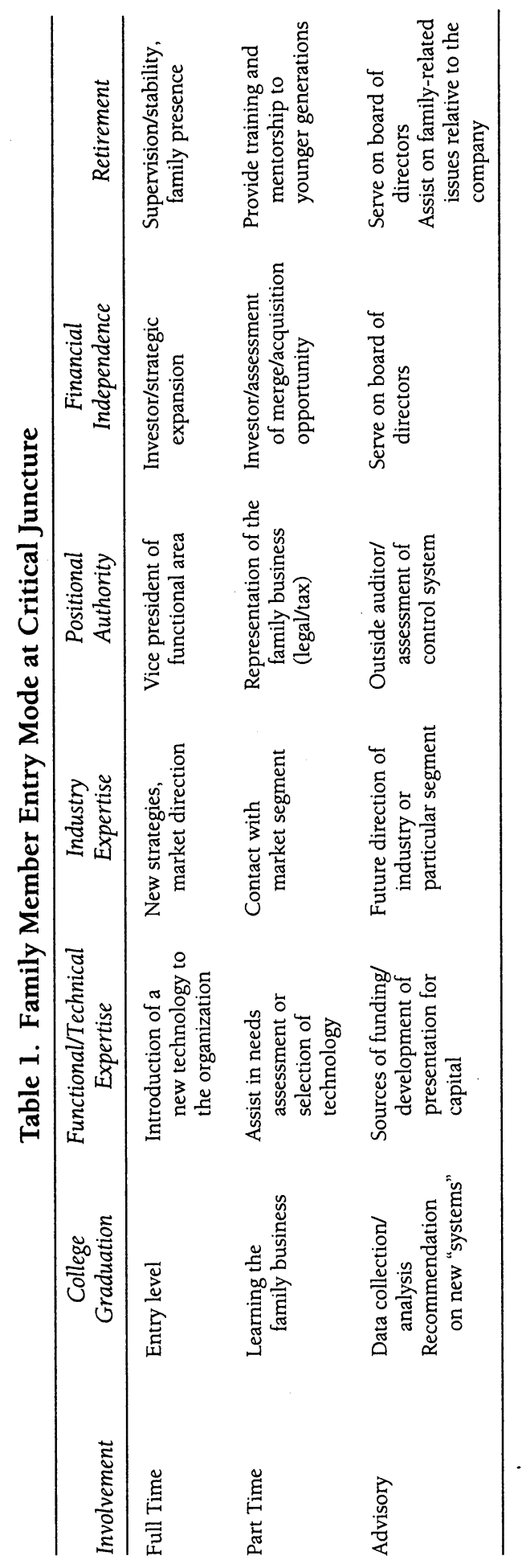


to manage in the process. These timing devices help reduce the probability of sibling conflict over succession in the family business.

Another series of stages in an individual's life that can provide insight into planning succession is the family life cycle. This cycle is regularly used by marketing managers and scholars to differentiate buying behavior for various stages in a family: (1) bachelor unit; (2) newly married couples; (3) full nest I: youngest child under six; (4) full nest II: youngest child over six; (5) full nest III: older married couples with dependent children; (6) empty nest I: older married couples, no children living with them, head labor force; (7) empty nest II: older married couple, no children living at home, head retired; (8) solitary survivor, in labor force; and (9) solitary survivor, retired (Kotler and Armstrong, 1991). Just as this cycle can be used by marketers to determine purchase motivation, products desired, availability of resources to purchase products, and so on, it can also be used to predict another set of critical personal junctures in a sibling's life.

The family life cycle signals stages in the sibling's personal life that can be used as indicators of preparation or inclination to assume some role in the family business. It has been suggested that life tasks are roughly linked to age, and, therefore, the life cycle concept can provide an approximation of the life stage (Levinson, 1978). Taken in conjunction with the career life cycle, the two concepts can provide useful information to the succession equation in a family business. With the addition of a similar concept from the business world, the business life cycle, succession planning takes on a temporal dimension relative to the individual (sibling), the family (founding generation or managing generation), and the family business. All the cycles contain critical information in planning and executing a successful succession.

Table 2 depicts the three separate cycles and proposes contributions that siblings might be expected to make at each stage. For example: family life cycle -empty nest; career strategic window-financial independence; company life cycle - early stage. This family member could relocate to assist in stabilizing a division of the family business; they also can cosign a debt, provide access to funds from his or her social network, and generally assist in stabilizing a family business in its early stages. This could be a sibling who did not enter the family business initially, had a successful professional life, and is now able to contribute at a later stage of the family and career life cycles. It could be asked, Can the family business be in the early stage? This can be explained by the family business having been divided into separate entities, with a division or company newly acquired or started by the family.

The importance of the career strategic windows, family life cycle, and business life cycle is that they help identify natural junctures that can be used to define entry times for siblings into the family business. Managing the prospective successors to the controlling generation within such a temporal format should prove to be beneficial to both generations involved in the succession process. The analysis also helps illustrate the multiple opportunities for siblings to enter the family business and the assets they bring to the company 


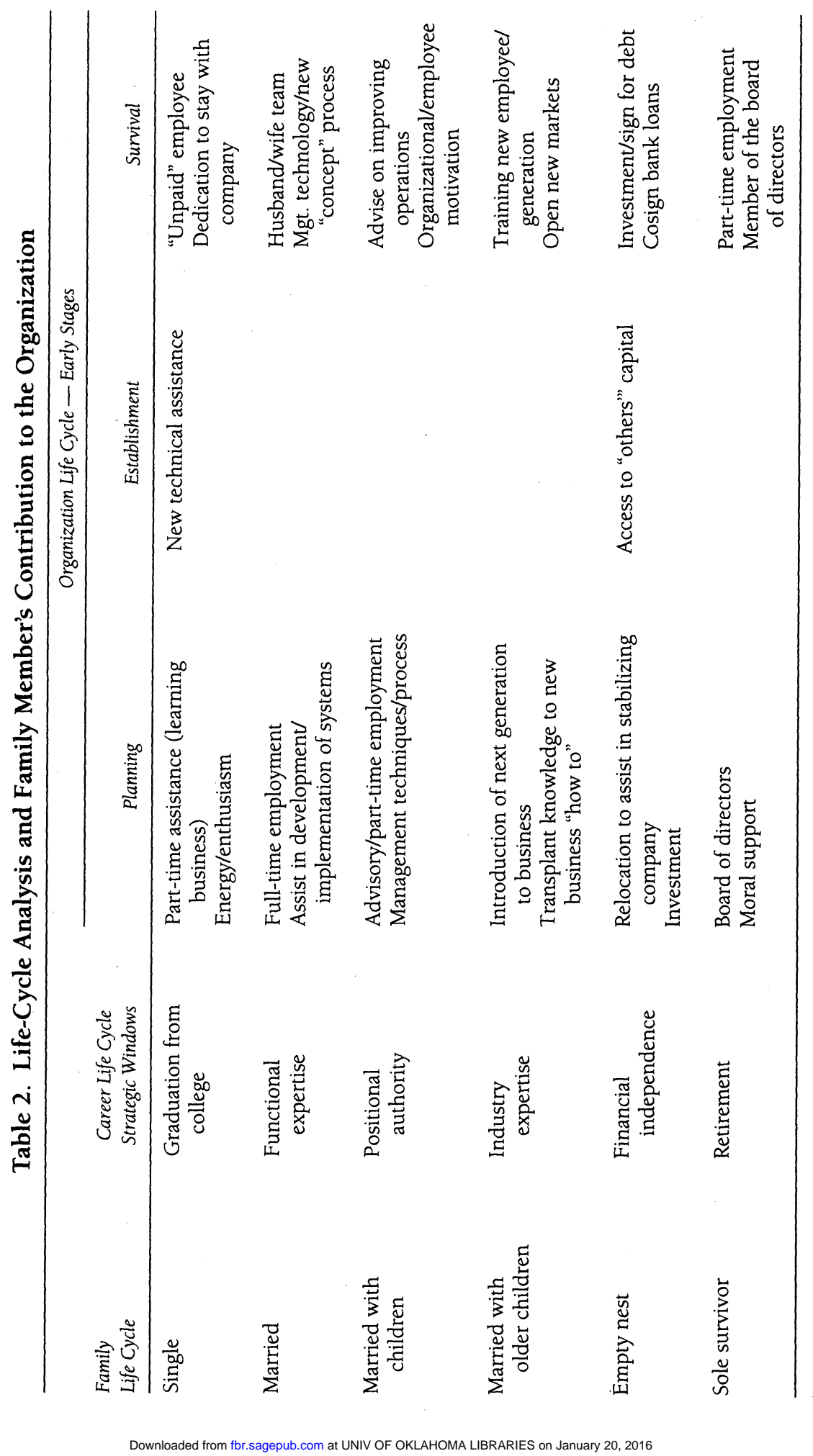




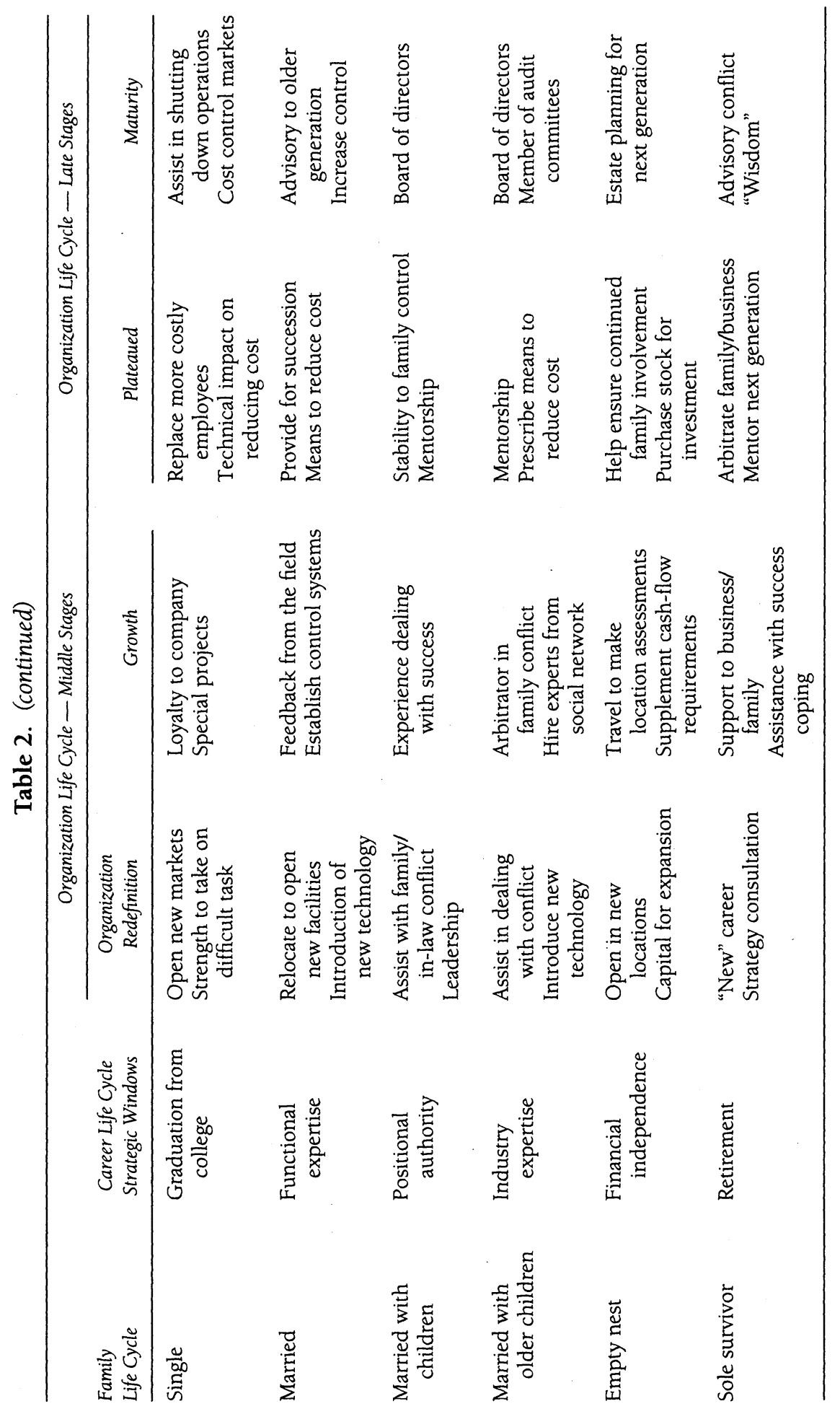


when they enter from different career and family life cycle stages. In addition, research propositions may be derived from these timing concepts that could prove to be beneficial to future researchers:

PROPOSITION 1. There are distinct, predictable, and multiple stages in the career development of siblings that are opportune times to enter a family business.

PROPOSITION 2. Family "elders" can successfully manage the entry of siblings into the family business based on the career stage of the individual.

PROPOSITION 3. Life cycle stages can be used to indicate the willingness or likelihood of family members to enter the family business.

PROPOSITION 4. Stages of career development and family life cycle can be combined as a predictive tool to determine the probability of siblings entering the family business.

PROPOSITION 5. Siblings entering the family business may have significantly different skills or attributes to contribute to the company based on their level of career development and stage in their family life cycle.

\section{Awareness of and Preparation for Unplanned Strategic Windows}

To this point, it has been assumed that the opportunity to enter the family business evolves incrementally from one stage of the career life cycle to the next. But the avenue to becoming an integral part of the family may be precipitated by a nonincremental event and disrupt the succession planning of the family. These less-predictable events normally are beyond the control or influence of the individual but, nonetheless, create a window (maybe strategic) to succeed the founder(s) in the family business. Such events as involuntary termination of a key employee, death in the family, inheritance, or divorce can create career vacuums that can produce the opportunity to take a leadership position in the family business.

The loss of one's job has obvious consequences: a negative impact on selfimage, restructured social networks, and decreased, if not eliminated, income flow, among others. This event also creates a critical juncture in a career life cycle. The stress and tension associated with this event frequently push individuals to plunge into another job without reflecting on their own desires for the future. With early retirements, extended job furloughs, and other creative dismissals with severance pay, prospective family members may have the time to undertake a critical assessment of their future goals and their potential contributions to the family business. This can put otherwise external employee status family members on a career path within the company when they use job loss as the trigger to "go do what I always wanted." So, even though the 
resultant attitude may be very different-from fear, stress, and disappointment on the one hand to anger, resentment, and relief on the other-the results are similar: the family business has what it needed, a successor. It is not infrequent that a family business is left with no family member working in the company except the founding generation. The unexpected entry of a sibling almost without regard to the reason can be construed by the family as being good for the company.

Other career-modifying events come unexpectedly but, nonetheless, present siblings with family business career options. One that has been chronicled frequently has been a divorced sibling returning to work for the family business to support dependent children. This critical time in a family unit sometimes drives the choice of radical means to meet present needs and to alter the future in a fundamental way. Multiple jobs and higher risk taking characterize this position. The thought of going into the family business, at least part-time, is appealing, and the additional money generated may be perceived as a substitute for the contributions of a spouse.

Just as with the incremental predictable phases, the sibling can make some preparation for nonincremental opportunities. A useful starting point of preparation is to have an aptitude and personality assessment completed early in one's career. These standardized tests help highlight careers for which an individual has an aptitude or may have an interest in developing in the future. These tests also help identify areas where individuals are not well suited. By having this inventory complete and updated on a timely basis, the family member can accomplish two important tasks: (1) address weakness in the skills section of the testing, and (2) become educated in sectors of the family business. Additional preparation activities can be undertaken by the sibling, such as taking training courses, attending trade shows, and interviewing with companies that are in the same business sector. In these situations, siblings are building an inventory of skills and knowledge on the family business, which may be of assistance to them in the future.

Preparing for nonincremental family business opportunities is a lifelong process. Actions and attitudes stimulate the development of one's portfolio of business knowledge and the social capital to be accepted in the family business. Constant attention should be given to building the motivation to become a member of the family business, even though this process might take a negative turn through divorce, death, or other misfortune. Converting that motivation into the drive and desire to contribute to the business will be challenging. Research propositions related to unplanned strategic windows would be as follows:

PROPOSITION 6. There are unplanned disruptions in the development of a career and family life cycle that "free" siblings to enter the family business.

PROPOSITION 7. Unplanned junctures to enter the family business can be prepared for by siblings. 


\section{Sibling Timing Decision Process}

The most appropriate timing for siblings to enter the family business varies from family to family, depending on the needs of the family business and on a host of personal issues. But entry strategies, as well as succession planning, should start early in the life of the sibling. Entrepreneurs who start planning their children's involvement and succession in their thirties and forties will have a higher probability of a successful family business succession than those who wait until their fifties and sixties (Danco, 1980, 1982). Therefore, a timing decision process would assist the founding/managing generation in establishing a formal evaluation process to manage sibling entry and the succession of power within the family business.

A process helpful in managing the timing of entry of siblings would have the following steps: (1) organizational and family life cycle assessment; (2) critical timing junctures in career and family life cycles assessment; (3) evaluation of timing options; (4) establishing timetable for each sibling; and (5) contingency analysis of timing issues. Each of these steps will be briefly discussed to illustrate key activities that take place in each step.

Step 1: Organizational and Family Life Cycle Assessment. The initial step in an entry timing decision process is to identify predictors of stages of development for siblings. At the same time, identification of business cycle predictors can be used to forecast the organizational needs of the family business. Several possible gauges of critical junctures have been suggested in this article, such as career strategic windows, family life cycle, and business life cycle. These may be joined by any other methods that can be used to provide some predictability to the future events in siblings' lives as well as in the family business's future. A set of predictors should be selected and used to formulate broad strategic timing alternatives between siblings and the family business. Other "outside" issues (in-laws, professionalization of management) would also be examined to ascertain what impact these variables might have on future succession in the company. The primary focus of this step is to identify predictors of events and to begin to track siblings and the evolution of the family business.

Step 2: Critical Time Junctures in Career and Family Life Cycles. This step in the process establishes timetables for siblings and attempts to identify areas of conflict. The conflict can occur between siblings (both are going to enter the family business at the same time) or for tradition-bound entrepreneurs whose oldest child is a daughter. Cycle analysis will alert the managing generation to potential problems. At the same time, an evolution of the family business and where its future managerial needs will be should be undertaken. The sibling evolution and the family business projected needs should then be overlaid to again determine potential conflicts or matches between sibling entry skills and organizational needs.

Step 3: Evaluation of Timing Options. This stage in the analysis examines the various options that the founding generation can use to "manage" the 
perceived or projected conflict between the sibling and the family business. This analysis scenario would extend periods of training or different levels in the career strategic windows cycle and the particular needs of the company. Delaying strategies, such as recommending additional education, can manipulate the sibling timing issue to suit the needs of the organization to reduce conflict with other siblings. This step could be subtitled the "what if" stage to examine alternatives to the projected intersection of the sibling and the family business.

Step 4: Establishing a Timetable for Each Sibling. The underlying rationale for this step is a "reality check" of the data that have already been assembled. To be accomplished successfully, the business family must put on their parental hat to see if the life cycle and career cycle are consistent with their parental judgment about each of their children. The process of managing sibling entry into the family business should be systematic but not necessarily clinical. The parents' feelings and emotions should be included in the analysis to ensure that the personal side of the family is accommodated in the decision process. The result of this stage is a realistic expectation schedule for sibling entry and level of involvement with the family business.

Step 5: Contingency Analysis of Timing Issues. This step examines the potential impact of sibling entry on other employees and their support for the next generation of family members. The analysis should seek potential problems that will occur after siblings have become a part of the family business. Again, the focus is on anticipating the source of conflict to avoid dysfunctional conflict or, at least, to be prepared for conflict if it occurs. The "what if" problem assessment will be beneficial to siblings for them to better understand their personal, as well as professional, impact on other employees and the future of the family business.

This sibling timing decision process provides for the following proposition:

PROPOSITION 8. Planning for the entry of siblings into the family business needs to start well before the siblings are "old enough" to become a member of the family business.

\section{Summary}

Family business and family conflict may interact to produce significant problems for family businesses. The conflict from the business may permeate the interfamily relations outside the family business, compounding the stress and dysfunctional conflict among the family members. Not all conflict is detrimental to the functioning of the family business, but some conflicts can have a negative impact on the effectiveness of the company. Succession within the family business can create dysfunctional conflict and uncertainty, and a large percentage of family businesses do not successfully make the transition from 
one generation to the next. Even if power is transferred in the family business, there is a high risk of a personal fallout between competing siblings for leadership and control of the business. It is not uncommon for the family business to lose a valuable employee who is a family member when there is competition for the power position within the business.

This article has examined conflict between and within the generations of the family business. We propose that succession planning be undertaken early in the life cycle of the firm. Timing and mode of entry are critical issues to be managed by the generation controlling and anticipating succession in the family business. It is suggested that timing sibling entry into the family business, career strategic windows, and the family life cycle can be coordinated in determining sibling entry. The needs of the family business can also be assisted by examining the business life cycle and making estimates of skills needed at each stage of this business cycle.

Conflict and disagreement between generations in a family business are among the most destructive forces the family business faces. The assets of the company, its personnel, and the loyalty that differentiates family businesses from other commercial organizations can all be lost without planning. Proactive planning and anticipation of potential conflict points may be the most important planning actions to take place in the family business. A long-range, step-by-step process should be initiated to ensure that conflict and its negative consequences are minimized in the family business.

\section{References}

Ambrose, D. M. (1983). Transfer of the family-owned business. Journal of Small Business Management, 21(1), 49-56.

Barach, J. A., Gantisky, J., Carson, J. A., \& Doochin, B. A. (1988). Entry of the next generation: Strategic challenges for family business. Journal of Small Business Management, 26,49-56.

Barnes, L. B. (1988). Incongruent hierarchies: Daughters and younger sons as company CEO's Family Business Review, 1(1), 9-21.

Barnes, L. B., \& Hershon, S. A. (1976). Transferring power in the family business. Harvard Business Review, 54(4), 105-114.

Beckhard, R., \& Dyer, W., Jr. (1983a). Managing change in the family firm-Issues and strategies. Sloan Management Review, 24, 59-65.

Beckhard, R., \& Dyer, W. G., Jr. (1983b). Managing continuity in the family-owned business. Organizational Dynamics, 12(2), 5-12.

Birley, S. (1986). Succession in the family firm: The inheritor's view. Journal of Small Business Management, 24, 36-43.

Blotnick, S. (1984). The case of the reluctant heirs. Forbes, 134, 180.

Bork, D. (1986). Family business, risky business. New York: American Management Association.

Christensen, C. (1953). Management succession in small and growing enterprises. Boston: Division of Research, Harvard Business School.

Churchill, N. C., and Hatten, K. J. (1987). Non-market-based transfers of wealth and power: A research framework for family businesses. American Journal of Small Business, 11(3), 51-64.

Cicirelli, V. G. (1985). Sibling relationships throughout the life cycle. In L. L'Abate (Ed.), The handbook of family psychology and therapy (Vol. 1). Homewood, IL: Dorsey Press.

Cohen, M. (1992). Passing the torch: Transfer strategies for your family business. Blue Ridge Summit, PA: Liberty Hall Press. 
Crane, M. A. (1982, February). How to keep families from feuding. Inc., pp. 73-74, 78-79.

Danco, L. (1980). Inside the family business. Cleveland: University Press.

Danco, L. (1982). Beyond survival. Cleveland: University Press.

Davis, P. (1982). Realizing the potential of family business. Organizational Dynamics, 12(1), 47-56.

Davis, S. (1968). Entrepreneurial succession. Administrative Science Quarterly, 13, 402-416.

Dumas, C. A. (1988, October). Succession dyads in family-owned businesses: A comparison of sons and daughters. Paper presented at the Research Day of the Family Firm Institute Conference, Boston.

Dumas, C. A. (1990). Managing the father-daughter succession process. Family Business Review, 3(2), 169-181.

Dyer, W. G. (1986). Cultural change in family firms: Anticipating and managing business and family transitions. San Francisco: Jossey-Bass.

Flamholtz, E. (1986). How to make the transition from an entrepreneurship to a professionally managed firm. San Francisco: Jossey-Bass.

Flemons, D. (1991). Completing distinctions. Boston: Shambhala.

Flemons, D., \& Cole, P. (1992). Connecting and separating family business: A relational approach to consulting. Family Business Review, 5(3), 257-269.

Friedman, S. D. (1991). Sibling relationships and intergenerational succession in family firms. Family Business Review, 4(1), 3-20.

Gillis-Donovan, J., \& Moynihan-Bradt, C. (1990). The power of the invisible women in the family business. Family Business Review, 3(2), 153-167.

Haley, J. (1980). Leaving home. New York: McGraw-Hill.

Hall, P. D. (1988). A historical overview of family firms in the United States. Family Business Review, 1(1), 51-68.

Handler, W. (1990). Succession in family firms: A mutual role adjustment between entrepreneur and next-generation family members. Entrepreneurship Theory and Practice, 15(1), 37-51.

Handler, W., \& Kram, K. (1988). Succession in family firms: The problem of resistance. Family Business Review, 1(4), 361-382.

Hollander, B. S., \& Bukowitz, W. R. (1990). Women, family cultures, and family business. Family Business Review, 3(2), 139-151.

Hollander, B. S., \& Elman, N. (1988). Family-owned business: An emerging field of inquiry. Family Business Review, 1(2), 145-164.

Jaffe, D. (1990). Working with the ones you love. Berkeley, CA: Conari Press.

Kanter, R. M. (1989). Work and family in the United States: A critical review and agenda for research and policy. Family Business Review, 2(1), 77-114.

Kaye, K. (1991). Penetrating the cycle of sustained conflict. Family Business Review, 4(1), 21-44.

Kepner, E. (1983). The family and the firm: A coevolutionary perspective. Organizational Dynamics, 12(1), 57-70.

Kets de Vries, M. (1985). The dark side of entrepreneurship. Harvard Business Review, 63(6), 160-167.

Kotler, P., \& Armstrong, G. (1991). Principles of marketing (5th ed.). Englewood Cliffs, NJ: Prentice Hall.

Lansberg, I. (1983). Managing human resources in family firms: The problem of institutional overlap. Organizational Dynamics, 12(1), 39-46.

Lansberg, I. S. (1986). Program for the study of family firms: Survey on succession and continuity. New Haven, CT: School of Organizational and Management, Yale University.

Lansberg, I. (1988). The succession conspiracy. Family Business Review, 1(1), 119-144.

Levinson, D. J. (1978). The seasons of a man's life. New York: Ballantine Books.

Levinson, H. (1971). Conflicts that plague family businesses. Harvard Business Review, 71(2), 90-98.

Longenecker, J. G., \& Schoen, J. E. (1975). An empirical investigation of pre-entry socialization of successors for leadership in family-controlled business. Paper presented at Management Perspectives on Organizational Effectiveness, Southern Management Association Meetings, Mississippi State University. 
Longenecker, J. G., \& Schoen, J. E. (1978). Management succession in the family business. Journal of Small Business Management, 16, 1-6.

Malone, S., \& Jenste, P. (1992). The problem of the plateaued owner-manager. Family Business Review, 5(1), 25-41.

Patrick, A. (1985). Family business: The offsprings' perception of work satisfaction and their working relationship with their father. Unpublished doctoral dissertation, Frilding Institute.

Peay, R., \& Dyer, W. (1989). Power orientations of entrepreneurs and succession planning. Journal of Small Business Management, 27(1), 47-51.

Poza, E. J. (1989). Smart growth: Critical choices for business continuity and prosperity. San Francisco: Jossey-Bass.

Prince, R. A. (1990). Family business mediation: A conflict resolution model. Family Business Review, 3(3), 209-223.

Rogal, K. H. (1989). Obligation or opportunity: How can could-be heirs assess their position? Family Business Review, 2(3), 237-255.

Rosenblatt, P. C., de Mik, L., Anderson, R. M., \& Johnson, P. A. (1985). The family in business: Understanding and dealing with the challenges entrepreneurial families face. San Francisco: JosseyBass.

Schein, E. (1983). The role of the founder in the creation of organizational culture. Organizational Dynamics, 12(1), 13-28.

Swogger, G. (1991). Assessing the successor generation in family business. Family Business Review, 4(4), 397-412.

Tashakori, M. (1980). Management succession: From the owner-founder to the professional president. New York: Praeger.

Ward, J. (1987). Keeping the family business healthy: How to plan for continuing growth, profitability, and family leadership. San Francisco: Jossey-Bass.

Whiteside, M., \& Brown, F. (1991). Drawbacks of a dual systems approach to family firms: Can we expand our thinking? Family Business Review, 4(4), 383-396.

Michael Harvey holds the Puterbaugh Chair of American Free Enterprise.

Rodney E. Evans is professor, Institute for Enterprise and Family Business, College of Business Administration, University of Oklahoma, Norman. 